Contents lists available at Journal Redwhitepress
Journal of Educational and Learning Studies
ISSN: 2655-2760 (Print) ISSN: 2655-2779 (Electronic)
Journal homepage: http://journal.redwhitepress.com/index.php/jles

\title{
The effect of arm muscle power and confidence on the ability of the volley smash ball
}

\author{
Tjung Hauw Sin ${ }^{\left.1^{*}\right)}$, Nopianto Nopianto ${ }^{2}$, Adnan Fardi ${ }^{3}$ \\ ${ }^{123}$ Universitas Negeri Padang
}

\begin{tabular}{l} 
Article Info \\
Article history: \\
Received Des $10^{\text {th }}, 2019$ \\
Revised Feb $24^{\text {th }}, 2020$ \\
Accepted Mar $20^{\text {th }}, 2020$ \\
\hline
\end{tabular}

\section{Keyword:}

Arm muscle power

Confidence

Smash ability

\begin{abstract}
The problem in this study originated from the low ability of the Smash of the men's volleyball players in the Palembang City MBVC Club, such as Smash not being on target, leaving the field and blocked. The low ability of Smash is influenced by several exogenous factors, including Arm muscle power and Confidence in Smash ability, and. This research is quantitative with a path analysis approach. The population in this study were all male volleyball players from the Palembang City MBVC Club, amounting to 20 people. Sampling uses a saturated sampling technique, so it samples all populations. The arm muscle instrument uses One Hand Medicine Ball Put, uses a Likert scale model questionnaire and Smash ability with the Smash test. The results showed that, (1) there was a direct effect of arm muscle power on the ability of Shash, with py $1=0.386$ or $14.90 \%$ (2) there was a direct trust effect on Shash ability, with py $2=0.382$ or $14.59 \%$ (3) There is an indirect effect of arm muscle power on the ability of Smash through self confidence, with py $21=$ 0.1574 or $15.74 \%$.
\end{abstract}

C 2020 The Authors. Published by Redwhitepress

This is an open access article under the CC BY-NC-SA license (https://creativecommons.org/licenses/by-nc-sa/4.0/

\section{Corresponding Author:}

Tjung Hauw Sin

Universitas Negeri Padang

Email: tjunghauwsin@konselor.org

\section{Introduction}

Sports coaching and development are part of efforts to realize the development of Indonesian people. In connection with the development and development of the Indonesian government of sports to form a national organization, KONI (Komite Olahraga Nasional Indonesia) which houses various sports in Indonesia. One sport that is developing in Indonesia is the volleyball game. So because many clubs have sprung up, then on January 22, 1955 PBVSI (Persatuan Bola voli Seluruh Indonesia) was formed in Jakarta for the first time. In addition, along with the establishment of the PBVSI in Indonesia, it held the first national volleyball championship. Since then, PBVSI was active in developing various kinds of volleyball activities both at home and abroad that continue until now. Physical condition is a part that becomes the main factor supporting an athlete to achieve an achievement.

The research aim to be achieved through this research is to determine the direct effect, indirect effect and simultaneous influence. To find out the direct influence of arm muscle power on the Smash ability of male volleyball players in the Palembang City MBVC Club To find out the direct influence of self confidence on the ability of the male volleyball player Smash of the Palembang City MBVC Club. son of the Palembang City 
MBVC Club. Smash is an accurate and sharp hit when the ball is in the air and the hand hits the top of the ball to be entered the opponent's area.

In volleyball all the attitude of hitting the ball into the opponent's area except service is an attack blow which is one of the main factors that can support to get points in a volleyball match. The factors that influence the volleyball player's ability to produce results are balance, flexibility, mastery of technique, mentality and so on (Prastyo, 2015).

There are three methods of attack which are all effective: they are spike, slow and smash, hard (Zhang, 2018). The smash technique is used as a weapon to attack and collect numbers in volleyball games (Akhmad \& Mesnan, 2019). Given the importance of this, implementing the smash technique in the competition must be effective. Various factors influence the ability of volleyball players, including: 1) talent, 2) physical abilities include: strength, endurance, speed, agility, flexibility, coordination, power, and stamina, 4) intelligence (Hasanah, 2013). One factor that influence to be able to play volleyball is a good physical condition factor (Hussain, 2018). One factor that influence to be able to play volleyball is a good physical condition factor (Sayyd, Zainuddin, Ghan, \& Altowerqi, 2020).

The arm is the upper limb comprising the upper arm, forearm and hand (Yunus \& Sunaryadi, 2010). Muscle strength is the ability to do movement with maximum effort (Gozlan et al., 2006; Zouita, Dziri, Ben Salah, \& Layouni, 2007). Power or explosive power is also called explosive power (Ismaryati, 2008). Power concerns the strength and speed of dynamic and explosive muscle contractions in the fastest time. In volleyball games, almost all technical activities use force (Buś ko, 2019). Arm muscles are the muscles of the whole hand from the base of the upper arm to the tip of the hand (Irodat, 2008). According to arm muscle power is the ability of a person to exert arm strength as much as possible to overcome a prisoner. One factor that influence the ability of smash is arm muscle strength (Purwocahyono, 2013).

Arm muscle strength is the driving force of the arm's continued movements which makes the result of a stronger stroke (Hiskya \& Wasa, 2019). A hard and fast smash is very effective in attacking opponents to get points(Lisdiantoro, 2016). To be able to produce a smash that is hard and fast it is very necessary Power or arm muscle explosive power (Schleichardt, Erber, Wolfarth, Beyer, \& Ueberschär, 2019). So arm muscle power is the ability to direct several muscles or a group of muscles to accept and hold the load while doing movements or work activities. Arm muscle power is the ability of several arm muscles in a short time to make a move. Believe yourself is something very important to have by someone does something.

Self-confidence (self-confidence) Confidence) is related to the philosophy of self-fulfillment (SelfFulfilling Prophecy) Fulfilling (Prophecy) and self-confidence (Self Efficacy). An athlete who has good selfconfidence, believes that he will be able to display sports performance as expected (Fitri \& Fuad, 2006). Confidence is one aspect of personality who is very important in human life (Iyan, 2014).Confidence as confidence in one's own abilities is adequate and aware of the capabilities possessed (Iyan, 2014). Self-confidence is a feeling that contains the strength, ability and skills to do and produce something that is based on a belief for success (Komarudin, 2013). Self-confidence is a positive attitude of an individual who enables him to develop assessments, both towards oneself and the environment or situation that it faces (Mirhan, 2016).

A lack of confidence can have a negative effect on individuals who experience it. Lack of confidence can affect anyone, regardless of age, gender, and so on (Vullioud, Clément, Scott-Phillips, \& Mercier, 2017). The effects of this lack of self-confidence such as feeling insecure, feeling tired, angry and difficult to concentrate (Li \& Kang, 2015). Based on some expert opinions above, we can conclude it that self-confidence has positive impacts on the following matters: 1) emotions, 2) concentration, 3) goals, 4) eff ort, 5) strategy, and 6) momentum. The benefits of self-confidence in sports are: 1) self-confidence can evoke positive emotions, 2) self-confidence can increase concentration, 3) self-confidence can achieve the goals to be achieved, 4) self-confidence can increase efforts, 5) self-confidence can affect the game strategy, 6) selfconfidence can affect psychological momentum, and 7) self-confidence can affect performance.

\section{Method}

The research method used in this research is an associative quantitative method with a path analysis approach. To test the significance of the path coefficient by using the t-test or F-test, to state whether the path coefficient is based on the results of the t-test. T-test was conducted to determine whether there is an influence between exogenous variables on endogenous variablesn (Engkos \& Kuncoro, 2012).

The variables that $\mathrm{d}$ in this study are arm muscle power (X1) as an independent variable (exogenous), and confidence (X2) as an intervening variable and also as an endogenous variable. While the dependent variable, the ability of volleyball Smash (Y). The population in this study were the men's volleyball players in 
the Palembang City MBVC Club with 20 people. Because of the very limited population, the determination of the sample in this study uses the saturation sampling technique.Saturated sampling is a sampling technique when all members of the population samples. I often do this is often if the population is small or less than 30 people or research that wants to make generalizations with tiny errors (Sugiyono, 2011). Based on the sampling technique used, the number of samples in this study was 20 people.

To measure arm muscle power is by doing One Hand Medicine Ball Put. Confidence in this study was measured using a range of scores with 5 alternative answers, for positive statements,: Agree (SS) with a score of 5, Agree (S) with a score of 4, Less Agree (KS) with a score of 3, Disagree (TS ) with a score of 2, and Disagree (STS) with a score of 1 . While for negative statements,: Agree (SS) with a score of 1 , Agree (S) with a score of 2, Less Agree (KS) with a score of 3, No Agree (TS) with a score of 4, and Disagree (STS) with a score of 5.The confidence institution in the study consisted of 54 statements that had been consulted with instrument experts validated by 3 experts in their fields. To measure the ability of Smash is by conducting a Smash ability test with a predetermined target box. In accordance with the research methodology and theoretical models that have been described, the data analysis technique used in the submission of hypotheses is Path Analysis. Data analysis includes: 1) data description, 2) test requirements analysis consisting of: data normality test and Linearity test, 3) path analysis which includes: model testing and hypothesis testing.

\section{Results and Discussions}

The description of the data in this study aims to describe the data characteristics of each variable,: Arm muscle power (X1), self-confidence (X2) and Smash (Y) ability of male baseball players at the MBVC Club in Palembang. The overall data of the variable is processed based on descriptive statistics, so that the highest value, the lowest value, the average value, and the standard deviation are got.

Arm muscle power data (x1) player of Male Volleyball Club MBVC Palembang City

Based on the data on the results of the arm muscle power test from 20 samples of male volleyball players from the MBVC Club in Palembang using One Hand Medicine Ball Put Test, the highest value was $8.32 \mathrm{~m}$, the lowest value was $5.75 \mathrm{~m}$, the mean was $7.39 \mathrm{~m}$ and the standard deviation of $0.74 \mathrm{~m}$. For more details about the frequency distribution of the results of the arm muscle power test results from 20 samples of male volleyball players from the MBVC Club in Palembang, see Table 5.

Table 5. Arm muscle power data (x1) player of Male Volleyball Club MBVC Palembang City

\begin{tabular}{cccc}
\hline No & Interval Class & \multicolumn{2}{c}{ Frequency } \\
\cline { 3 - 4 } & & Absolut & Relatif (\%) \\
\hline $\mathbf{1}$ & $>8,51$ & 0 & 0,00 \\
\hline $\mathbf{2}$ & $7,77-8,50$ & 7 & 35,00 \\
\hline $\mathbf{3}$ & $7,02-7,76$ & 7 & 35,00 \\
\hline $\mathbf{4}$ & $6,28-7,01$ & 4 & 20,00 \\
\hline $\mathbf{5}$ & $<6,27$ & 2 & 10,00 \\
\hline & Total & 20 & 100,00 \\
\hline
\end{tabular}

Based on table 5 above, that the results of the Arm muscle Power test results from 20 samples of male volleyball players from the MBVC Club in Palembang City, got interval classes are above $8.51 \mathrm{~m} 0$ people $(0.00 \%)$, interval classes7.77-8, $50 \mathrm{~m} 7$ people $(35.00 \%)$, interval classes $7.02-7.76 \mathrm{~m} 7$ people $(35.00 \%)$, class intervals $6.28-7.01 \mathrm{~m} 4$ people (20.00\%), and interval classes below $6.27 \mathrm{~m}$ are 2 people (10.00\%).

\section{Confidence data (X2) player of Male Volleyball Club MBVC Palembang City}

Based on the data of the confidence results of 20 samples of male volleyball players from the Palembang City MBVC Club using a questionnaire, the highest score was 207.00, the lowest score was 190.00 , the mean (Mean) was 188.75 and the standard deviation was 5.18. For more details about the frequency distribution of the results of confidence from 20 samples of male volleyball players from the MBVC Club in Palembang, see the table 6 . 
Table 5. Confidence data (X2) player of Male Volleyball Club MBVC Palembang City

\begin{tabular}{cccc}
\hline No & Interval Class (Score) & \multicolumn{2}{c}{ Frequency } \\
\cline { 3 - 4 } & & Absolut & Relatif (\%) \\
\hline $\mathbf{1}$ & $>207$ & 2 & 10,00 \\
\hline $\mathbf{2}$ & $201-206$ & 6 & 30,00 \\
\hline $\mathbf{3}$ & $196-200$ & 6 & 30,00 \\
\hline $\mathbf{4}$ & $191-195$ & 5 & 25,00 \\
\hline $\mathbf{5}$ & $<190$ & 1 & 5,00 \\
\hline
\end{tabular}

Based on table 6, that the confidence data from 20 samples of male volleyball players from the MBVC Club in Palembang City, got interval classes above 2072 people (10.00\%), interval classes 201-206 6 people $(30.00 \%)$, class intervals $196-2006$ people $(30.00 \%)$, class intervals $191-1955$ people $(25.00 \%)$, and interval classes under 1901 person $(5.00 \%)$.

\section{Smash Ability Data (Y) Male Volleyball Player MBVC Club Palembang City}

Based on the results of the Smash ability test results from 20 samples of male volleyball players in the Palembang City MBVC Club using the Smash test with a predetermined target box, the highest score was 13.00 , the lowest score was 6.00 , the mean was 9,80 and the standard deviation of 2.12. For more details on the frequency distribution of Smash ability test results from 20 samples of male volleyball players in the Palembang City, I can see MBVC Club in the table.

\begin{tabular}{cccc}
\hline No & Interval Class (Score) & \multicolumn{2}{c}{ Frequency } \\
\cline { 3 - 4 } & & Absolut & Relatif (\%) \\
\hline $\mathbf{1}$ & $>13$ & 2 & 10,00 \\
\hline $\mathbf{2}$ & $11-12$ & 6 & 30,00 \\
\hline $\mathbf{3}$ & $9-10$ & 7 & 35,00 \\
\hline $\mathbf{4}$ & $7-8$ & 3 & 15,00 \\
\hline $\mathbf{5}$ & $<6$ & 2 & 10,00 \\
\hline & Total & 20 & 100,00 \\
\hline
\end{tabular}

Arm Muscle Power Data Normality Test (X1). Based on the results of the Kolmogorov-Smirnov normality test data for arm muscle power (X1) with the help of the SPSS program version 24.0, we know the Asymp value. Sig $=0.078>\alpha=0.05$. Thus, it can be concluded that the arm muscle power data is distributed. Confidence Data Normality Test (X2) Based on the results of the Kolmogorov-Smirnov normality test data confidence (X2) with the help of SPSS program version 24.0, the Asymp value is known. Sig $=0,200>\alpha=$ 0,05 . Thus, it can be concluded that confidence data is distributed. Smash (Y) Ability Data Normality Test Based on the results of the Kolmogorov-Smirnov data normality Smash (Y) capability with the help of SPSS version 24.0, the Asymp value is known. Sig $=0,200>\alpha=0,05$. Thus, it can be concluded that the Smash ability data is distributed. Linearity Test of Arm Muscle Power Data (X1) with Smash Ability (Y) Based on the results of the analysis of Variance for testing Linearity between Arm muscle power with Smash ability, we obtained the Sig value. $=0.998>\alpha=0.05$, we can conclude it that the model of the relationship be Confidence Data Linearity Test (X2) with Smash Ability (Y) Based on the results of the analysis of Variance for testing Linearity between self confidence and Smash ability, the value of Sig. $=0.171>\alpha=0.05$, it can be concluded that the relationship model between the confident variable (X2) and the Smash ability (Y) is Linear.

Individual tests conducted $\mathrm{X} 1$ against $\mathrm{Y}$ got the results of the path coefficient $\rho \mathrm{Y} 1=0.386$. Based on the results of calculations performed using the SPSS program version 24.00 , the Sig. $0.010<\alpha=0.05$, so in this case, $\mathrm{Ha}$ is accepted and it rejects $\mathrm{H} 0$, which means the path analysis coefficient is significant. This means that there is a direct influence of the arm muscle power on the ability of the men's volleyball player Smash Club Palembang City Palembang. To find out the magnitude of the direct influence of the arm muscle Power on the ability of the men's volleyball player Smash of the Palembang City MBVC Club $=\rho_{\mathrm{y} 1}{ }^{2} \times 100 \%=0,386^{2} \times 100 \%$ $=14,90 \%$. Based on the above, we can conclude it that the magnitude of the direct influence of arm muscle power on the ability of the male volleyball player Smash of the MBVC Club Palembang City is $14.90 \%$. 
Individual tests conducted X2 against $\mathrm{Y}$ got the path coefficient $\rho Y 2=0.382$. Based on the results of calculations performed using the SPSS program version 24.00, the Sig. $0.022<\alpha=0.05$, so in this case, Ha is accepted and it rejects H0, which means the path analysis coefficient is significant. There is a direct influence of confidence on the ability of the men's volleyball player Smash MBVC Club Palembang. To find out, the magnitude of the direct influence of confidence on the ability of the men's volleyball player Smash of the MBVC Club Palembang City: $=\rho_{\mathrm{y} 2}^{2} \times 100 \%=0,382^{2} \times 100 \%=14,59 \%$

Based on the results of the analysis test, to look for the indirect effect of arm muscle power on Smash ability through the confidence of the men's volleyball player in the Palembang City MBVC Club in the results of the path coefficient multiplication ( $\rho 31)$ with $(\rho y 2)$, the following results are got:

$\begin{array}{ll}\text { Indirect influence } & \rho_{31} \times \rho_{\mathrm{y} 3} \\ & 0,412 \times 0,382 \\ & 0,1574\end{array}$

\begin{tabular}{lll}
\hline Contribution & $\boldsymbol{p}_{\boldsymbol{y} 31}$ & $0,1574 \times 100 \%$ \\
& & $15,74 \%$
\end{tabular}

Based on data analysis, we can conclude it that the magnitude of the indirect effect of arm muscle power on Smash ability through the confidence of men's volleyball players in the Palembang City MBVC Club is $15.74 \%$. Based on research that has been done, that there is a direct effect of arm muscle power on the Smash ability of men's volleyball players in the Palembang City MBVC Club with $\rho$ y $1=0.386$ and Sig. $=$ $0.010<\alpha=0.05$. The results show that the magnitude of the direct influence of arm muscle power on the Smash ability of men's volleyball players in the Palembang City MBVC Club is $14.90 \%$.

Based on research that has been done, that there is a direct influence of self-confidence on the ability of men's volleyball players Smash the MBVC Club Palembang City with $\rho$ y $2=0.382$ and Sig. $0.022<\alpha=0.05$. The results show that the magnitude of the direct influence of confidence on the ability of men's volleyball players Smash the Palembang City MBVC Club is $14.59 \%$. Based on the test results of the analysis of the arm muscle Power variable on the ability of Smash through the confidence of male volleyball players in the Palembang City MBVC Club, got $=0.1574$. The results show that the magnitude of the indirect effect of arm muscle power on Smash ability through the confidence of the male volleyball player in the MBVC Club in Palembang is $15.74 \%$.

\section{Conclusions}

Individual tests conducted X2 against $\mathrm{Y}$ got the path coefficient $\rho Y 2=0.382$. Based on the results of calculations performed using the SPSS program version 24.00, the Sig. $0.022<\alpha=0.05$, so in this case, Ha is accepted and it rejects $\mathrm{H} 0$, which means the path analysis coefficient is significant. There is a direct influence of confidence on the ability of the men's volleyball player Smash MBVC Club Palembang. To find out, the magnitude of the direct influence of confidence on the ability of the men's volleyball player Smash of the MBVC Club Palembang City.

\section{References}

Akhmad, I., \& Mesnan. (2019). Model Learning approach to spike a volleyball Play for junior high school students. In I. I., Y. Y., K. K., \& R. R. (Eds.), 1st International Conference on Education, Science and Technology 2019, ICESTech 2019 (Vol. 1387). https://doi.org/10.1088/1742-6596/1387/1/012057

Buśko, K. (2019). Power-velocity relationship and muscular strength in female volleyball players during preparatory period and competition season. Acta of Bioengineering and Biomechanics, 21(2), 31-36. https://doi.org/10.5277/ABB-01323-2019-02

Engkos, R., \& Kuncoro, A. (2012). Cara Menggunakan Dan Memaknai Analisis Jalur (Path Analysis). Alphabeta, Bandung.

Fitri, Y., \& Fuad, N. (2006). Kepercayaan Diri dan Prestasi Atlet Taekwondo Daerah Istimewa Yokyakarta. Jurnal Psikologi Universitas Diponegoro, 3(1).

Gozlan, G., Bensoussan, L., Coudreuse, J.-M., Fondarai, J., Gremeaux, V., Viton, J.-M., \& Delarque, A. 
(2006). Isokinetic dynamometer measurement of shoulder rotational strength in healthy elite athletes (swimming, volley-ball, tennis): Comparison between dominant and nondominant shoulder. Annales de Readaptation et de Medecine Physique, 49(1), 8-15. https://doi.org/10.1016/j.annrmp.2005.07.001

Hasanah, M. (2013). Pengaruh Latihan Pliometrik Depth Jump Dan Jump To Box Terhadap Power Otot Tungkai Pada Atlet Bolavoli Klub Tugumuda Kota Semarang. Universitas Negeri Semarang.

Hiskya, H. J., \& Wasa, C. (2019). Effect of double leg bound exercise on explosive capability of leg muscle power in the UnmuS volleyball men's team. International Journal of Mechanical Engineering and Technology, 10(2), 1453-1460. Retrieved from https://www.scopus.com/inward/record.uri?eid=2-s2.085063557856\&partnerID $=40 \&$ md5 $=4 \mathrm{e} 3 \mathrm{cb} 2 \mathrm{c} 006 \mathrm{a} 5316 \mathrm{fcfbbb3a1da78552 \textrm {d }}$

Hussain, A. A. J. (2018). Effect of physical effort due to increased intensity in biochemical variables in blood and some basic skills of volleyball players. Journal of Global Pharma Technology, 10(3), 858-866. Retrieved from https://www.scopus.com/inward/record.uri?eid=2-s2.085050762079\&partnerID=40\&md5=2c7f9f5c28201d0c7a06eef82dd846df

Irodat, B. (2008). Sumbangan Daya Ledak Otot Tungkai, Kekuatan Otot Lengan, Dan Kelentukan Pergelangan Tangan Terhadap Hasil Smash Semi Dalam Permainan Bolavoli Pada Siswa Putra Ekstrakurikuler Bolavoli Man Kalibeber Wonosobo Tahun 2008.

Ismaryati. (2008). Tes dan Pengukuran Olahraga. Surakarta: UNP Press.

Iyan, A. . (2014). Iyan, A.R. (2014). Buku Pintar Tampil Percaya Diri. Yogyakarta: Araska. Yogyakarta: Araska.

Komarudin. (2013). Psikologi Olahraga. Bandung: Remaja Rosda Karya.

Li, J., \& Kang, H. (2015). Status quo of the will of Chinese professional volleyball players. Open Cybernetics and Systemics Journal, 9(1), 1189-1194. https://doi.org/10.2174/1874110X01509011189

Lisdiantoro, G. (2016). Hubungan Antara Koordinasi Mata Tangan, Power Otot Lengan dan Kekuatan Otot Perut dengan Kemampuan Pukulan Smash dalam Permainan Bulutangkis. Premiere Educandum: Jurnal Pendidikan Dasar Dan Pembelajaran, 6(02).

Mirhan, J. B. K. J. (2016). Hubungan Antara Percaya Diri Dan Kerja Keras Dalam Olahraga Dan Keterampilan Hidup. Jorpres (Jurnal Olahraga Prestasi), 12(1).

Prastyo, A. H. (2015). Pengaruh Fleksibilitas Togok dan Kekuatan Otot Tungkai Terhadap Kemampuan Smash Dalam Permainan Bola Volly Pada Siswa Putra Kelas Xi Smk PGRI 4 Kediri Tahun Ajaran 2014/2015.

Purwocahyono, M. W. (2013). Hubungan Antara Kekuatan Otot Lengan, Kekuatan Otot Punggung, Kekuatan Otot Tungkai Dan Koordinasi Mata-Tangan Dengan Kemampuan Servis Atas Bolavoli Siswa Putra Smp Kanisius Gayam Yogyakarta.

Sayyd, S. M., Zainuddin, Z. A. B., Ghan, D. Z. B. A., \& Altowerqi, Z. M. (2020). Sports activities for undergraduate students in Saudi Arabia universities: A systematic literature review. International Journal of Human Movement and Sports Sciences, 8(1), 1-16. https://doi.org/10.13189/saj.2020.080101

Schleichardt, A., Erber, C., Wolfarth, B., Beyer, C.-N., \& Ueberschär, O. (2019). Physiological adaptations in the dominant and non-dominant shoulder in male competitive junior volleyball players . Sports Orthopaedics and Traumatology, 35(1), 22-30. https://doi.org/10.1016/j.orthtr.2019.01.007

Sugiyono. (2011). Metode Penelitian Kuantitatif, Kualitatif dan $R \& D$. Bandung: Alfabeta.

Vullioud, C., Clément, F., Scott-Phillips, T., \& Mercier, H. (2017). Confidence as an expression of commitment: Why misplaced expressions of confidence backfire. Evolution and Human Behavior, 38(1), 9-17.

Yunus, U., \& Sunaryadi, Y. (2010). Kinesiologi. Jakarta: Departemen Pendidikan dan Kebudayaan.

Zhang, G. (2018). Exploration on applying the tactical serve in the volleyball match. IPPTA: Quarterly Journal of Indian Pulp and Paper Technical Association, 30(7), 146-149. Retrieved from https://www.scopus.com/inward/record.uri?eid=2-s2.0$85061695867 \&$ partnerID $=40 \& \mathrm{md} 5=\mathrm{f} 839 \mathrm{c} 9 \mathrm{a} 0 \mathrm{bc} 87 \mathrm{~b} 1 \mathrm{f} 24051238 \mathrm{eea} 24 \mathrm{a} 9 \mathrm{~b} 4$

Zouita, A., Dziri, C., Ben Salah, F.-Z., \& Layouni, R. (2007). Comparison of isokinetic muscle strength and ratio hamstring/quadriceps between Tunisian athletes . Science and Sports, 22(5), 196-200. https://doi.org/10.1016/j.scispo.2007.08.001 